\title{
ZRÓŻNICOWANIE ZMIENNYCH MAKROEKONOMICZNYCH ORAZ ROZWOJU REGIONÓW CZĘŚCI AZJATYCKIEJ FEDERACJI ROSYJSKIEJ
}

\begin{abstract}
Celem opracowania jest analiza rozwoju ekonomicznego oraz zróżnicowanie regionów części azjatyckiej Federacji Rosyjskiej (FR) na podstawie wskaźników taksonomicznych i analizy konwergencji/dywergencji dotyczących pięciu zmiennych makroekonomicznych. Zmiennymi tymi są: stopa bezrobocia rejestrowanego, inwestycje per capita, ${ }^{2}$ produkt krajowy brutto $(\mathrm{PKB})$ per capita, płace oraz liczba organizacji prowadzących działalność badawczo-rozwojową $(\mathrm{B}+\mathrm{R})^{3}$ na $1 \mathrm{mln}$ mieszkańców w latach 2000-2012. W opracowaniu rozważania dotyczą 27 regionów FR, dane użyte do analiz zaś pochodzą ze strony Rosyjskiego Urzędu Statystycznego (Федералная Служба Государственной Статистики; www.gks.ru). Do części azjatyckiej FR zaliczyć można trzy następujące okręgi federalne: Uralski Okręg Federalny, Syberyjski Okręg Federalny oraz Dalekowschodni Okręg Federalny ${ }^{4}$. Podstawową metodą analizy jest wskaźnik taksonomiczny oparty na metryce euklidesowej.

Przestrzenne zróżnicowanie rozwoju regionów FR pokazuje specyfikę oraz charakter regionów azjatyckich Rosji. Wykonane analizy prowadzą do wniosku, iż najlepiej rozwinięte pod względem analizowanych zmiennych regiony mają charakter przemysłowowydobywczy, z kolei najsłabiej rozwinięte - charakter rolniczy.

Układ pracy jest następujący: w 2. punkcie zostanie omówione przestrzenne zróżnicowanie zmiennych makroekonomicznych w regionach FR, to jest: stopy bezrobocia rejestrowanego, poziomu płac, liczba organizacji prowadzących działalność badawczorozwojową $(\mathrm{B}+\mathrm{R})$ na 1 mln mieszkańców, inwestycji per capita oraz PKB per capita; w punkcie 3. przedstawiona została budowa wskaźnika taksonomicznego opartego na metryce euklidesowej; punkt 4. zawiera analizę zróżnicowania rozwoju regionów FR opartą na wskaźnikach taksonomicznych, w punkcie 5. przedstawiona została wstępną analiza konwergencji/dywergencji, natomiast punkt 6 zawiera podsumowania i ważniejsze wnioski. Słowa kluczowe: Federacja Rosyjska, Azjatyckie regiony Federacji Rosyjskiej, rozwój ekonomiczny, zróżnicowanie zmiennych makroekonomicznych.
\end{abstract}

\footnotetext{
${ }^{1}$ Mgr Aleksy Kornowski, Instytut Ekonomii i Zarządzania, Uniwersytet Jagielloński, e-mail: aleks.kornowski@uj.edu.pl

${ }^{2}$ Wszystkie zmienne wyrażone w jednostkach pieniężnych przeliczono na PLN według kursu NBP z 31 grudnia $2012 \mathrm{r}$.

${ }^{3}$ Badanie i Rozwój.

${ }^{4}$ Według danych ze strony www.gks.ru.
} 


\section{WSTĘP}

Analizując rozwój gospodarki FR, należy pamiętać o specyfice rozwoju ekonomicznego poszczególnych części kraju. Pod względem rozwoju ekonomicznego Rosję można rozdzielić na dwie części. Część europejską oraz azjatycką. Część europejska charakteryzuje się większą liczbą mieszkańców oraz stosunkowo słabo rozwiniętym przemysłem wydobywczym. Natomiast w części azjatyckiej występuje dobrze rozwinięty przemysł wydobywczy oraz przetwórczy, przy stosunkowo nie dużej liczbie mieszkańców. ${ }^{5}$

Do części azjatyckiej FR zaliczyć można trzy następujące okręgi federalne: Uralski Okręg Federalny, Syberyjski Okręg Federalny oraz Dalekowschodni Okręg Federalny6. Podstawową metodą analizy jest wskaźnik taksonomiczny oparty na metryce euklidesowej. Na rysunku 1 przedstawiono 3 badane okręgi federalne na mapie Federacji Rosyjskiej.

Rys. 1. Azjatyckie Okręgi Federalne Federacji Rosyjskiej

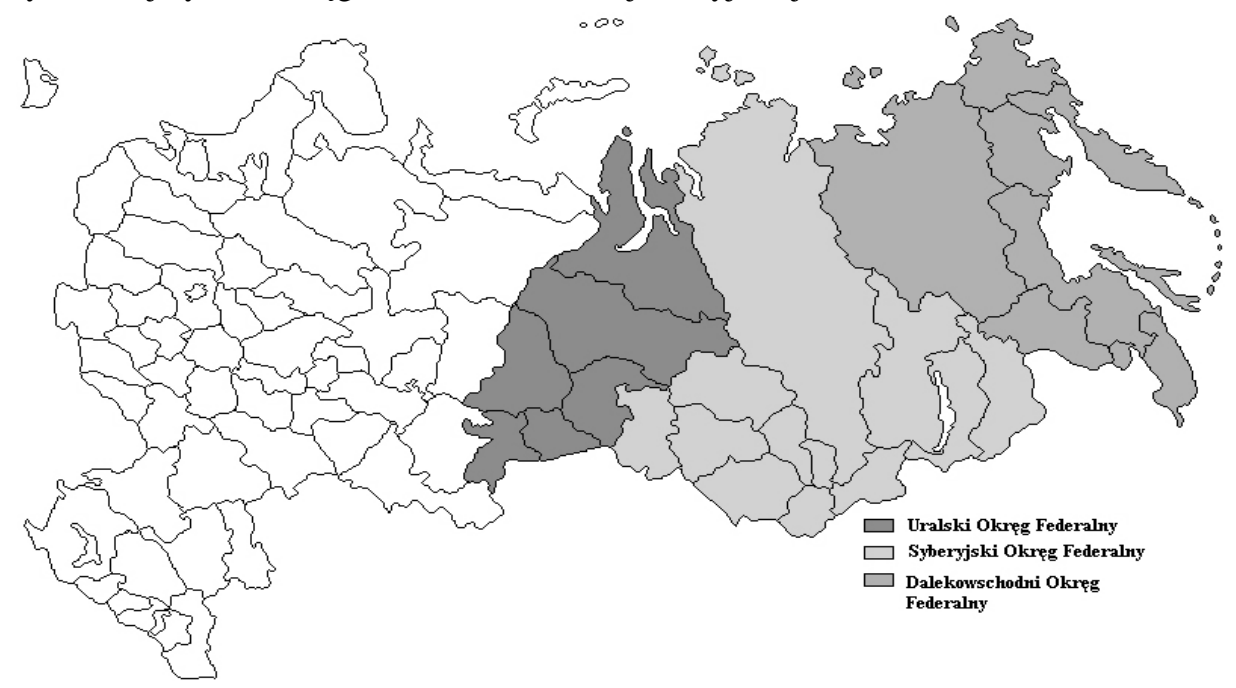

Źródło: opracowanie własne na podstawie danych na stronie www.gks.ru.

Podział badanych okręgów federalnych na regiony przedstawiono w tabeli 1.

\footnotetext{
${ }^{5}$ Według danych ze strony www.gks.ru
} ${ }^{6}$ Według danych ze strony www.gks.ru. 
Tabela 1. Podział okręgów federalnych na regiony

\begin{tabular}{|c|l|}
\hline Okręg federalny & \multicolumn{1}{c|}{\begin{tabular}{c}
\multicolumn{1}{c|}{ Regiony wchodzące w skład okręgu } \\
federalnego
\end{tabular}} \\
\hline \multirow{1}{*}{ Uralski } & $\begin{array}{l}\text { Obwód kurgański, obwód swierdłowski, } \\
\text { obwód tiumeński } \\
\text { Chanty-Mansyjski Okręg Autonomiczny, } \\
\text { Jamalsko-Nieniecki Okręg Autonomiczny, } \\
\text { obwód czelabiński }\end{array}$ \\
\hline Syberyjski & $\begin{array}{l}\text { Republika Ałtaju, Republika Buriacji, } \\
\text { Republika Tuwy, Republika Chakasji, } \\
\text { Kraj Ałtajski, Kraj Zabajkalski, } \\
\text { Kraj Krasnojarski, obwód irkucki, } \\
\text { obwód kemerowski, obwód nowosybirski, } \\
\text { obwód omski, obwód tomski }\end{array}$ \\
\hline Źródło: opracowanie własne na podstawie danych na stronie www.gks.ru . \\
\hline Dalekowschodni \\
$\begin{array}{l}\text { Republika Jakucji, Kraj Kamczacki, } \\
\text { Kraj Nadmorski, Kraj Chabarowski, } \\
\text { obwód amurski, obwód magadański, } \\
\text { obwód sachaliński, Źydowski Obwód } \\
\text { Autonomiczny, Czukocki Okręg } \\
\text { Autonomiczny }\end{array}$ \\
\hline
\end{tabular}

W pracy omówiono przestrzenne zróżnicowanie zmiennych makroekonomicznych w regionach części azjatyckiej FR. Następnie przedstawiono budowę wskaźnika taksonomicznego opartego na metryce euklidesowej. Zawarto w niej również analizę zróżnicowania rozwoju regionów FR opartą na wskaźnikach taksonomicznych oraz porównano stopień przestrzennego zróżnicowania badanych zmiennych oraz dokonano wstępnej analizy $\sigma$-konwergencji owych zmiennych makroekonomicznych.

\section{PRZESTRZENNE ZRÓŻNICOWANIE WYBRANYCH ZMIENNYCH MAKROEKONOMICZNYCH W REGIONACH FEDERACJI ROSYJSKIEJ}

\subsection{Stopa bezrobocia rejestrowanego}

Na rysunku 2 przedstawiono przestrzenne zróżnicowanie stopy bezrobocia rejestrowanego w latach 2000-2012. 
Rys. 2. Przestrzenne zróżnicowanie stóp bezrobocia (\%) rejestrowanego w latach 2000-2012

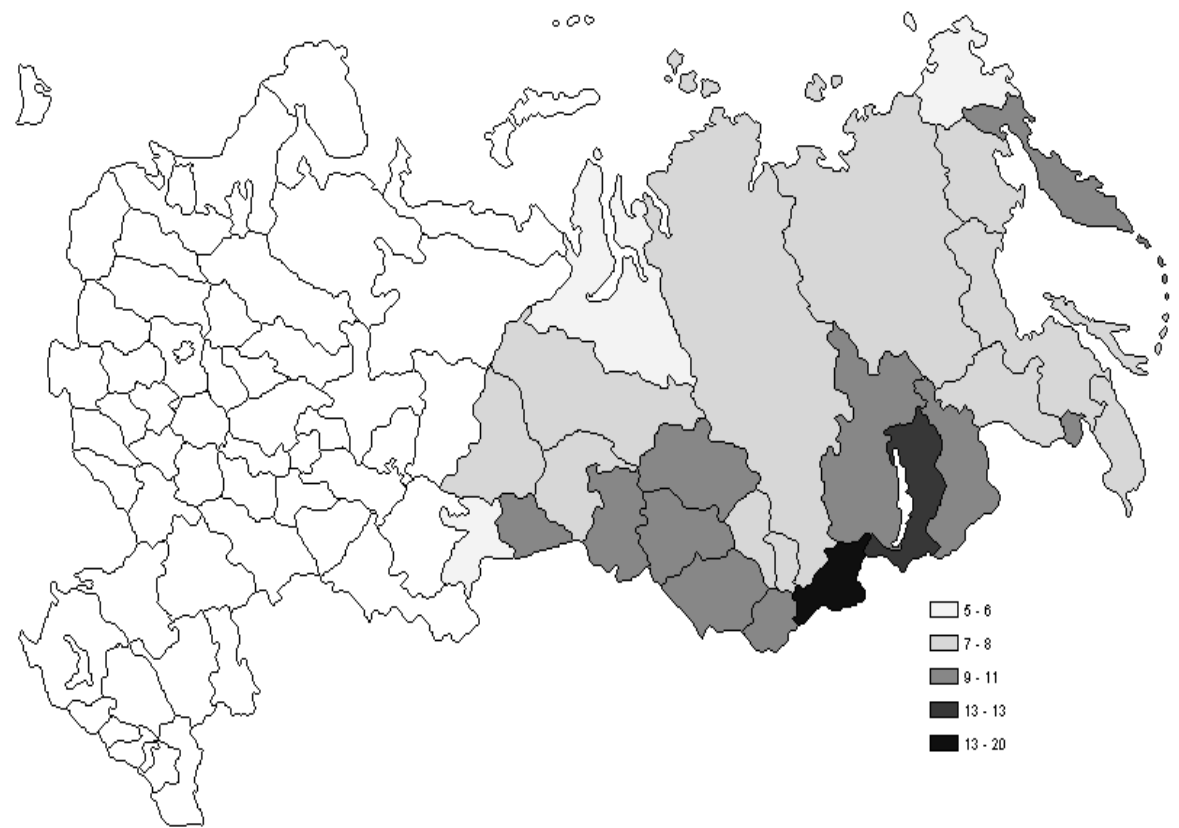

Źródło: opracowanie własne na podstawie danych na stronie www.gks.ru .

Z przedstawionej mapy wyciągnąć można następujące wnioski:

- najniższa stopa bezrobocia rejestrowanego była odnotowana w Okręgach Autonomicznych: Czukockim i Jamalsko-Nienieckim oraz obwodach: czelabińskim, magadańskim, swierdłowskim oraz tiumeńskim;

- najwyższa stopa bezrobocia występowała w obwodach: tomskim, irkuckim, kurgańskim oraz w Republikach Tuwy i Buriacji.

W tabeli 2 przedstawiono zróżnicowanie stopy bezrobocia $\mathrm{w}$ regionach części azjatyckiej FR w latach 2000-2012, w podziale na grupy kwartylowe.

Tabela 2. Przestrzenne zróżnicowanie stopy bezrobocia (\%) rejestrowanego w regionach części azjatyckiej FR w latach 2000-2012

\begin{tabular}{|c|c|l|}
\hline $\begin{array}{c}\text { Grupa } \\
\text { kwartylowa }\end{array}$ & $\begin{array}{c}\text { Granice } \\
\text { grupy }\end{array}$ & \multicolumn{1}{c|}{ Regiony } \\
\hline 1 & $<7,95$ & $\begin{array}{l}\text { Czukocki Okręg Autonomiczny }(5,09), \\
\text { Jamalsko-Nieniecki Okrég Autonomiczny }(5,50), \text { obwód } \\
\text { czelabiński }(6,20), \text { obwód magadański }(7,20), \text { obwód } \\
\text { swierdłowski }(7,28), \text { obwód tiumeński7 } \\
\text { Chabarowski }(7,72)\end{array}$ \\
\hline
\end{tabular}

\footnotetext{
${ }^{7}$ Okręgi Autonomiczne Jamalsko-Nieniecki oraz Chanty-Mansyjski są przedstawione osobno, mimo że administracyjnie zaliczane są do obwodu Tiumeńskiego.
} 


\begin{tabular}{|c|c|l|}
\hline 2 & $7,95-8,82$ & $\begin{array}{l}\text { Kraj Krasnojarski (8,17), Chanty-Mansyjski Okręg } \\
\text { Autonomiczny }(8,27), \text { obwód sachaliński (8,48), obwód } \\
\text { kemerowski }(8,63), \text { Kraj Nadmorski }(8,63), \text { obwód amurski } \\
(8,79), \text { Republika Chakasji }(8,82)\end{array}$ \\
\hline 3 & $8,83-9,68$ & $\begin{array}{l}\text { Republika Jakucji }(8,84), \text { obwód nowosybirski (9), obwód } \\
\text { omski (9,02), Kraj Ałtajski (9,2), } \\
\text { Żydowski Obwód Autonomiczny (9,22), Kraj Kamczacki } \\
\text { (9,66) }\end{array}$ \\
\hline$>9,69$ & $\begin{array}{l}\text { Obwód tomski (9,7), obwód irkucki (9,85), obwód kurgański } \\
(11,07), \text { Republika Ałtaju (11,58), Kraj Zabajkalski (11,63), } \\
\text { Republika Buriacji (13,73), Republika Tuwy (20,35) }\end{array}$ \\
\hline
\end{tabular}

Źródło: opracowanie własne na podstawie danych na stronie www.gks.ru.

Rozważając dane przedstawione w tabeli 2, można zauważyć, że przestrzenne zróżnicowanie stopy bezrobocia w regionach części azjatyckiej FR w latach 2000-2012 jest następujące:

a) Najniższa stopa bezrobocia, nieprzekraczająca 7,95\%, notowana była w regionach: Czukockim Okręgu Autonomicznym (5,09\%), JamalskoNienieckim Okręgu Autonomicznym (5,5\%), obwodzie czelabińskim $(6,2 \%)$, obwodzie magadańsim $(7,2 \%)$, obwodzie swierdłowskim $(7,28 \%)$, obwodzie tiumeńskim(7,52\%), Kraju Chabarowskim (7,72\%).

Do tej grupy należą regiony $\mathrm{z}$ dobrze rozwiniętym przemysłem wydobywczym, jak w przypadku Okręgów Autonomicznych Czukockiego i Jamalsko-Nienieckiego oraz obwodu magadańskiego. Dobrze rozwinięty sektor usługowy oraz sektor B + R występuje w obwodach tiumeńskim, czelabińskim oraz swierdłowskim.

b) Niska stopa bezrobocia występowała w następujących regionach: Kraju Krasnojarskim (8,17\%), Chanty-Mansyjskim Okręgu Autonomicznym $(8,27 \%)$, obwodzie sachalińskim $(8,48 \%)$, obwodzie kemerowskim $(8,63 \%)$, Kraju Nadmorskim (8,63\%), obwodzie amurskim (8,79\%), Republice Chakaskiej $(8,82 \%)$.

c) Wysoka stopa bezrobocia notowana była w: Republice Jakucji $(8,84 \%)$, obwodzie nowosybirskim (9\%), obwodzie omskim (9,02\%), Kraju Ałtajskim (9,2\%), Żydowskim Obwodzie Autonomicznym $(9,22 \%)$ oraz Kraju Kamczackim $(9,66 \%)$.

d) Najwyższa stopa bezrobocia, której wartość przekraczała 9,68\%, występowała w następujących regionach: obwodzie tomskim $(9,7 \%)$, obwodzie irkuckim $(9,85 \%)$, obwodzie kurgańskim $(11,07 \%)$, Republice Ałtaju (11,58\%), Kraju Zabajkalskim (11,63\%) oraz Republikach Buriacji $(13,73 \%)$ i Tuwy $(20,35 \%)$.

W przedstawionej grupie (d) znalazły się regiony ze stosunkowo słabo rozwiniętym sektorem przemysłowym i usługowym. Są to w większości regiony rolnicze. Owe regiony również charakteryzują się niskim poziomem PKB per capita (por. tabela 4). 


\subsection{Inwestycje per capita}

Przestrzenne zróżnicowanie inwestycji na mieszkańca w latach 2000-2012 przedstawiono na rys. 3 .

Rys. 3. Przestrzenne zróżnicowanie inwestycji na mieszkańca w latach 2000-2012

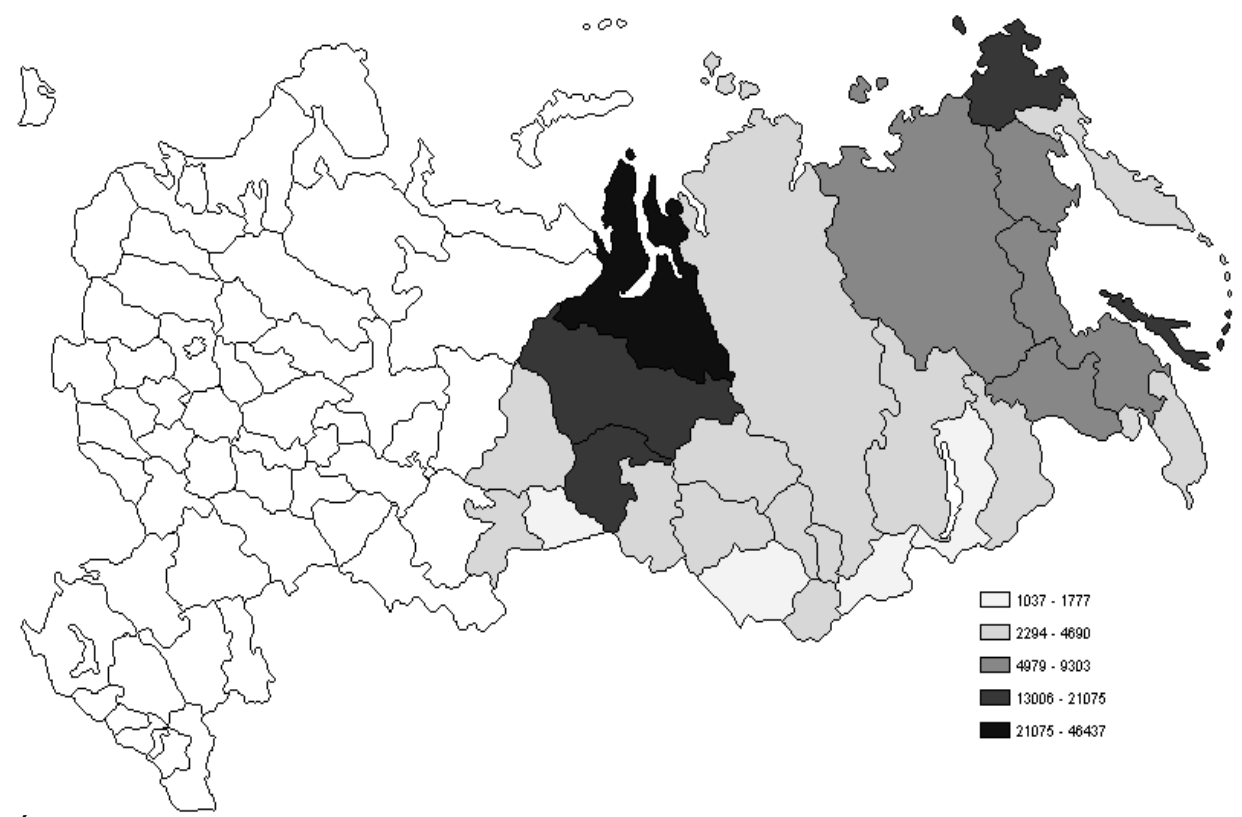

Źródło: opracowanie własne na podstawie danych na stronie www.gks.ru.

Na podstawie rys. 3 można sformułować następujące wnioski:

- zdecydowanie najwyższą wartością analizowanej zmiennej makroekonomicznej, charakteryzował się w latach 2000-2012 JamalskoNieniecki Okręg Autonomiczny. Inwestycje per capita w owym okresie wynosiły 46 437,85 PLN;

- najniższa wartość zmiennej makroekonomicznej występowała w Republice Tuwy i wynosiła 1037,17 PLN.

$\mathrm{W}$ tabeli 3 przedstawiono przestrzenne zróżnicowanie inwestycji per capita $\mathrm{w}$ latach 2000-2012, w podziale na grupy kwartylowe. 
Tabela 3. Przestrzenne zróżnicowanie inwestycji per capita (PLN) przy cenach stałych z 2012 r. w latach 2000-2012

\begin{tabular}{|c|c|l|}
\hline $\begin{array}{c}\text { Grupa } \\
\text { kwartylowa }\end{array}$ & Granice grupy & \multicolumn{1}{c|}{ Regiony } \\
\hline 1 & $<2403,51$ & $\begin{array}{l}\text { Republika Tuwy (1037,13), Kraj Ałtajski (1331,24), } \\
\text { obwód kurgański (1700,39), Republika Buriacji } \\
(1777,71), \text { obwód omski (2294,82), Kraj Zabajkalski } \\
(2341,47), \text { Republika Ałtaju (2343,66) }\end{array}$ \\
\hline 2 & $2403,51-4063,12$ & $\begin{array}{l}\text { Obwód nowosybirski (2463,38), Republika Chakasji } \\
\text { (2506,88), obwód czelabiński (2659,53), obwód } \\
\text { irkucki (2844,79), obwód swierdłowski (3337,71), } \\
\text { obwód kemerowski (3424,06), Kraj Nadmorski } \\
\text { (4063,12) }\end{array}$ \\
\hline 3 & $4063,13-5383,85$ & $\begin{array}{l}\text { Kraj Kamczacki (4266,37), obwód tomski (4555,07), } \\
\text { Żydowski Obwód Autonomiczny (4629,05), Kraj } \\
\text { Krasnojarski (4690,65), Kraj Chabarowski (4979,65), } \\
\text { obwód amurski (5131,13). }\end{array}$ \\
\hline 4 & $>5383,85$ & $\begin{array}{l}\text { obwód magadański (5636,57), Republika Jakucji } \\
\text { (9303,23), Czukocki Okręg Autonomiczny (13006,43), } \\
\text { obwód sachaliński (17892,29), obwód tiumeński } \\
\text { (19142,33), Chanty-Mansyjski Okręg Autonomiczny } \\
\text { (21075,90), Jamalsko-Nieniecki Okręg Autonomiczny } \\
\text { (46437,85) }\end{array}$ \\
\hline
\end{tabular}

Źródło: opracowanie własne na podstawie danych na stronie www.gks.ru.

Przestrzenne zróżnicowanie inwestycji per capita w latach 2000-20012 (tab. 3) przedstawia się następująco:

a) najniższa wartość inwestycji per capita (nieprzekraczająca 2403,52 PLN) charakterystyczna była dla: Republiki Tuwy (1037,17), Kraju Ałtajskiego (1331,24), obwodu kurgańskiego (1700,39), Republiki Buriacji (1777,71), obwodu omskiego (2294,82), Kraju Zabajkalskiego (2341,47), Republiki Ałtaju $(2343,66)$ oraz obwodu nowosybirskiego $(2463,38)$.

Do tej grupy (a) należą regiony najmniej atrakcyjne dla inwestorów ze względu na słabo rozwinięty sektor przemysłowy, wydobywczy lub rolniczy charakter regionu. Obwody nowosybirski oraz omski znalazły się w tej grupie ze względu na dużą liczbę mieszkańców, a także ponieważ w tych obwodach występuje dobrze rozwinięty sektor przemysłowy oraz usługowy;

b) niski poziom inwestycji per capita (2403,52-4063,12 PLN) występował w regionach: Republice Chakasji $(2506,88)$, obwodzie czelabińskim $(2659,53)$, obwodzie irkuckim (2844,79), obw. swierdłowskim $(3337,71)$, obw. kemerowskim $(3424,06)$ oraz Kraju Nadmorskim $(4063,12)$;

c) wysoki poziom inwestycji per capita (4063,12-5383,85 PLN) notowany był w regionach: Kraju Kamczackim (4266,37), obwodzie tomskim (4555,07), Żydowskim Obwodzie Autonomicznym (4629,05), Kraju Krasnojarskim $(4690,65)$, Kraju Chabarowskim $(4979,65)$ oraz obwodzie amurskim $(5131,13)$;

d) najwyższym poziomem inwestycji per capita (przekraczającym 5383,85 PLN) charakteryzowały się następujące regiony: obwód magadański $(5636,57)$, 
Republika Jakucji (9303,23), Czukocki Okręg Autonomiczny (13006,43), obwód sachaliński (17892,29), obwód tiumeński (19142,33), Chanty-Mansyjski Okręg Autonomiczny oraz Jamalsko-Nieniecki Okręg Autonomiczny $(46437,85)$.

Do przedstawionej grupy (d) zaliczyć można najbardziej atrakcyjne regiony dla inwestorów ze względu na aktywnie rozwijający się w regionach sektor wydobywczy oraz przemysłowy.

\subsection{Produkt krajowy brutto per capita}

Rysunek 4 odzwierciedla przestrzenne zróżnicowanie PKB per capita w latach 2000_ 2012.

Rys. 4. Przestrzenne zróżnicowanie PKB per capita w latach 2000-2012

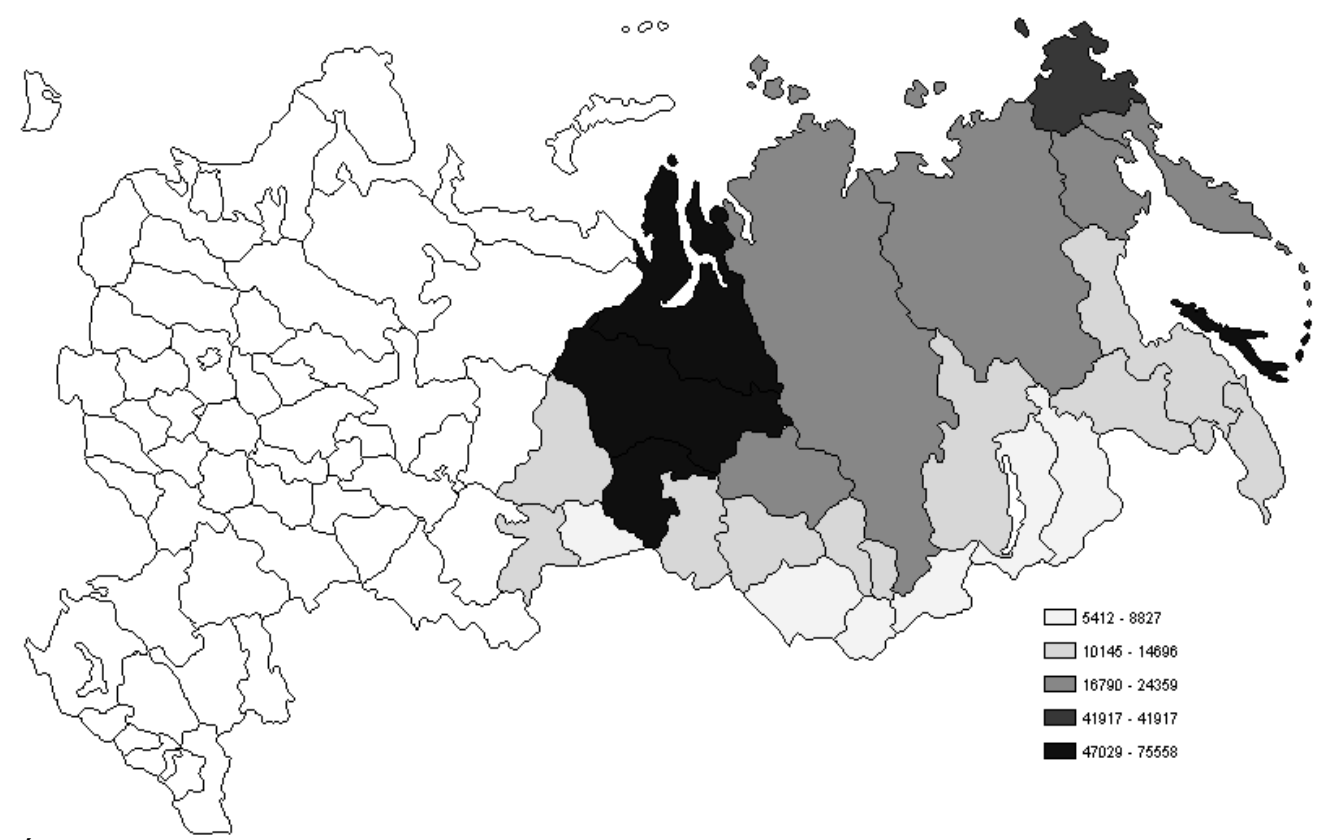

Źródło: opracowanie własne na podstawie danych na stronie www.gks.ru.

Na podstawie rysunku 4 można sformułować następujące wnioski.

- $\quad$ zdecydowanie najwyższą wartością PKB per capita charakteryzowały się Okręgi Autonomiczne: Jamalsko-Nieniecki oraz Chanty-Mansyjski;

- najniższa wartość występowała w Republice Tuwy i Ałtaju oraz Kraju Ałtajskim. W tabeli 4 zestawiono grupy kwartylowe ze względu na zróżnicowanie PKB per capita w części azjatyckiej FR w latach 2000-2012. 
Tabela 4. Przestrzenne zróżnicowanie produktu krajowego brutto per capita (PLN) przy cenach stałych z 2012 r. w latach 2000-2012

\begin{tabular}{|c|c|c|}
\hline $\begin{array}{c}\text { Grupa } \\
\text { kwartylowa }\end{array}$ & Granice grupy & Regiony \\
\hline 1 & $<10258,03$ & $\begin{array}{l}\text { Republika Tuwy (5412,13), Republika Ałtaju } \\
(6275,52), \text { Kraj Ałtajski (7091,68), Kurgański } \\
\text { obw. (7380,05), Republika Buriacji }(8649,82) \text {, } \\
\text { Kraj Zabajkalski }(8827,29), \text { Żydowski Obwód } \\
\text { Autonomiczny }(10145,5)\end{array}$ \\
\hline 2 & $10258,04-12801,84$ & $\begin{array}{l}\text { Republika Chakasji (10 370,56), obwód } \\
\text { nowosybirski obw. (11 095,41), obwód omski (11 } \\
\text { 778,41), obwód czelabiński }(11 \text { 801,12), obwód } \\
\text { amurski (12 111,79), Kraj Nadmorski (12 354,9), } \\
\text { obwód kemerowski (12 801,84) }\end{array}$ \\
\hline 3 & $12801,85-20680,88$ & $\begin{array}{l}\text { Obwód irkucki (13 178,85), obwód swierdłowski } \\
(14408,37), \text { Kraj Chabarowski }(14 \text { 696,43), obwód } \\
\text { tomski }(16790,85), \text { Kraj Kamczacki }(17 \text { 624,6), } \\
\text { Kraj Krasnojarski }(19902,85)\end{array}$ \\
\hline 4 & $>20680,89$ & $\begin{array}{l}\text { obwód magadański (21 458,92), Republika Jakucji } \\
(24 \text { 359,45), Czukocki Okręg Autonomiczny (41 } \\
\text { 917,59), obwód sachaliński (47 029,82), obwód } \\
\text { tiumeński (64 467,52), Chanty-Mansyjski Okręg } \\
\text { Autonomiczny (70 056,65), Jamalsko-Nieniecki } \\
\text { Okręg Autonomiczny (75 558,82) }\end{array}$ \\
\hline
\end{tabular}

Źródło: opracowanie własne na podstawie danych na stronie www.gks.ru.

Przestrzenne zróżnicowanie PKB per capita w regionach części azjatyckiej FR w latach 2000-2012 można scharakteryzować następująco:

a) najniższa wartość PKB per capita brutto (nieprzekraczająca 10 258,03 PLN) występowała w następujących regionach: Republice Tuwy (5412,13), Republice Ałtaju (6275,53), Kraju Ałtajskim (7091,68), obwodzie kurgańskim (7380,05), Republice Buriacji $(8649,82)$, Kraju Zabajkalskim $(8827,29)$ oraz Żydowskim Obwodzie Autonomicznym (10 145,50).

W grupie (a) znalazły się regiony ze słabo rozwiniętym sektorem usługowym oraz wysoką stopą bezrobocia rejestrowanego (por. tabela 4);

b) niska wartość PKB per capita brutto (10 258,03 - 12 801,84 PLN) odnotowana była w następujących regionach: Republice Chakasji (10 370,56), obwodzie nowosybirskim (11 095,41), obwodzie omskim (11 778,41), obwodzie czelabińskim (11 801,12), obwodzie amurskim $(12$ 111,79), Kraju Nadmorskim (12 354,9) oraz obwodzie kemerowskim $(12$ 801,84);

c) wysoka wartość PKB per capita brutto (12 801,84 - 20 680,88 PLN) występowała w następujących regionach: obwodzie irkuckim $(13$ 178,85), obwodzie swierdłowskim (14 408,37), Kraju Chabarowskim (14 696,43), obwodzie tomskim $(16790,85)$, Kraju Kamczackim $(17$ 624,6) oraz Kraju Krasnojarskim (19 902,85); 
d) najwyższa wartość PKB per capita brutto (od 20 680,88 PLN) odnotowana była w następujących regionach: obwodzie magadańskim (21 458,92), Republice Jakucji $(24$ 359,45), Czukockim Okręgu Autonomicznym (41 917,59), obwodzie sachalińskim (47 029,82), obwodzie tiumeńskim (64 467,52), ChantyMansyjskim Okręgu Autonomicznym (70 056,65) oraz Jamalo-Nienieckim Okręgu Autonomicznym (75 558,82).

Do tej grupy (d) należą regiony $\mathrm{z}$ dobrze rozwiniętym sektorem wydobywczym oraz przemysłowym. Charakteryzują się one również niską stopą bezrobocia rejestrowanego (por. tabela 2).

\subsection{Płace}

Przestrzenne zróżnicowanie płac w latach 2000-2012 przedstawiono na rysunku 5.

Rys. 5. Przestrzenne zróżnicowanie płac w latach 2000-2012

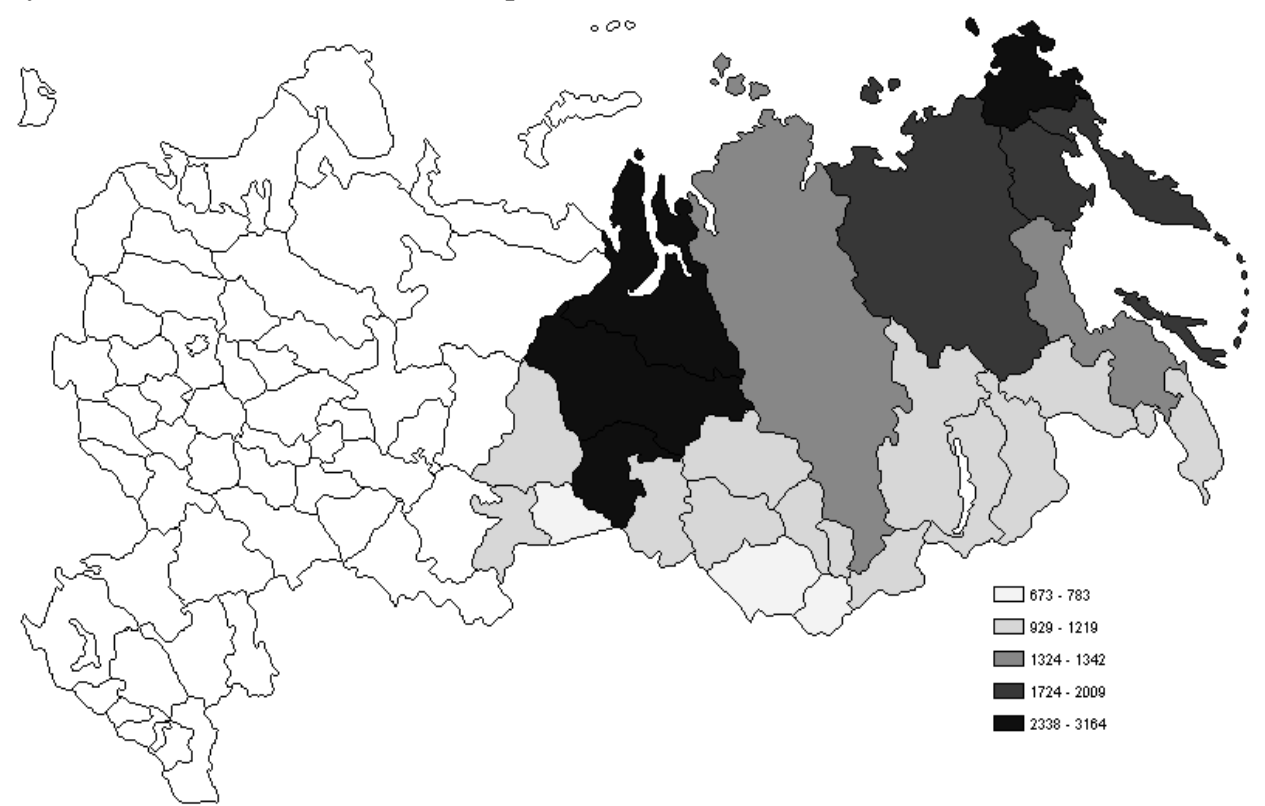

Źródło: opracowanie własne na podstawie danych na stronie www.gks.ru.

Z rysunku 5 wynika:

- najwyższy poziom płac w badanym okresie występował w obwodach sachalińskim, magadańskim, tiumeńskim oraz w Okręgach Autonomicznych: Chanty-Mansyjskim, Czukockim i Jamalsko-Nienieckim;

- najniższa płaca występowała w Kraju Ałtajskim, obwodach kurgańskim, omskim, czelabińskim oraz w Republikach Ałtaju, Tuwy i Buriacji.

Przestrzenne zróżnicowanie płac w regionach części azjatyckiej FR w latach 2000-2012, w podziale na grupy kwartylowe przedstawiono w tabeli 5. 
Tabela 5. Przestrzenne zróżnicowanie płac w regionach części azjatyckiej FR w latach 2000-2012

\begin{tabular}{|c|c|l|}
\hline $\begin{array}{c}\text { Grupa } \\
\text { kwartylowa }\end{array}$ & Granice grupy & \multicolumn{1}{c|}{ Regiony } \\
\hline 1 & $<1002,89$ & $\begin{array}{l}\text { Kraj Ałtajski (673,12), obwód kurgański (749,37), } \\
\text { Republika Ałtaju (783,11), obwód omski (929,77), } \\
\text { Republika Tuwy (948,35), obwód czelabiński } \\
(985,75), \text { Republika Buriacji (996,31) }\end{array}$ \\
\hline 2 & $1002,90-1163,09$ & $\begin{array}{l}\text { Obwód nowosybirski (1009,47), Republika } \\
\text { Chakasji (1015,41), obwód kemerowski (1047,55), } \\
\text { Kraj Zabajkalski (1051,38), Żydowski Obwód } \\
\text { Autonomiczny (1073,2), obwód swierdłowski } \\
(1126,35), \text { obwód irkucki (1163,09) }\end{array}$ \\
\hline 3 & $1163,1-1843,73$ & $\begin{array}{l}\text { Obwód amurski (1180,07), Kraj Nadmorski } \\
(1182,53), \text { obwód tomski (1219,75), Kraj } \\
\text { Krasnojarski (1324,08), Kraj Chabarowski } \\
(1342,36), \text { Republika Jakucji (1724,15) }\end{array}$ \\
\hline \multirow{2}{*}{4} & $>1843,74$ & $\begin{array}{l}\text { Kraj Kamczacki (1963,32), obwód sachaliński } \\
(1967,47), \text { obwód magadański (2009,57), obwód } \\
\text { tiumeński (2338,91), Chanty-Mansyjski Okręg } \\
\text { Autonomiczny (2614,54), Czukocki Okręg } \\
\text { Autonomiczny (2745,82), Jamalsko-Nieniecki } \\
\text { Okręg Autonomiczny (3164,65) }\end{array}$ \\
\hline
\end{tabular}

Źródło: opracowanie własne na podstawie danych na stronie www.gks.ru.

Analizując dane zawarte w tabeli 5, można zauważyć, że przestrzenne zróżnicowanie płac w regionach części azjatyckiej FR w latach 2000-2012 jest następujące:

a) najniższa płaca (nieprzekraczająca 1002,89 PLN) charakterystyczna była dla: Kraju Ałtajskiego $(673,12)$, obwodu kurgańskiego (749,37), Republiki Ałtaju $(783,11)$, obwodu omskiego $(929,77)$, Republiki Tuwy $(948,35)$, obwodu czelabińskiego $(985,75)$ oraz Republiki Buriacji $(996,31)$.

$\mathrm{W}$ grupie (a) znalazły się regiony ze słabo rozwiniętym sektorem wydobywczym. W większości są to regiony przemysłowe lub rolnicze;

b) niska płaca (1002,89-1163,09 PLN) występowała w regionach: obwodzie nowosybirskim (1009,47), Republice Chakasji (1015,41), obwodzie kemerowskim $(1047,55)$, Kraju Zabajkalskim $(1051,38)$, Żydowskim Obwodzie Autonomicznym $(1073,2)$, obwodzie swierdłowskim $(1126,35)$ oraz obwodzie irkuckim $(1163,09)$;

c) wysoka płaca (1163,09-1843,73 PLN) notowana była w: obwodzie amurskim (1180,07), Kraju Nadmorskim (1182,53), obwodzie tomskim $(1219,75)$, Kraju Krasnojarskim $(1324,08)$, Kraju Chabarowskim $(1324,36)$ oraz Republice Jakucji $(1724,15)$;

d) najwyższą płaca (przekraczającą 1843,73 PLN) charakteryzowały się regiony: Kraj Kamczacki $(1963,32)$, obwód sachaliński $(1967,47)$, obwód magadański $(2009,57)$, obwód tiumeński $(2338,91)$, Chanty-Mansyjski Okręg Autonomiczny 
$(2614,54)$, Czukocki Oręg Autonomiczny $(2745,82)$ oraz Jamalsko-Nieniecki Okręg Autonomiczny $(3164,65)$.

Do przedstawionej grupy (d) należą regiony $\mathrm{z}$ dobrze rozwiniętym wydobywczym oraz przemysłowym sektorami.

\subsection{Liczba organizacji $B+R$ w regionie na 1 mln mieszkańców}

$\mathrm{Na}$ rysunku 6 odzwierciedlono liczbę organizacji o charakterze badawczorozwojowym w regionach części azjatyckiej FR w latach 2000-2012 w przeliczeniu na 1 mln mieszkańców.

Rys. 6. Liczba organizacji o charakterze badawczo-rozwojowym w regionach części azjatyckiej FR w latach 2000-2012 na 1 mln mieszkańców

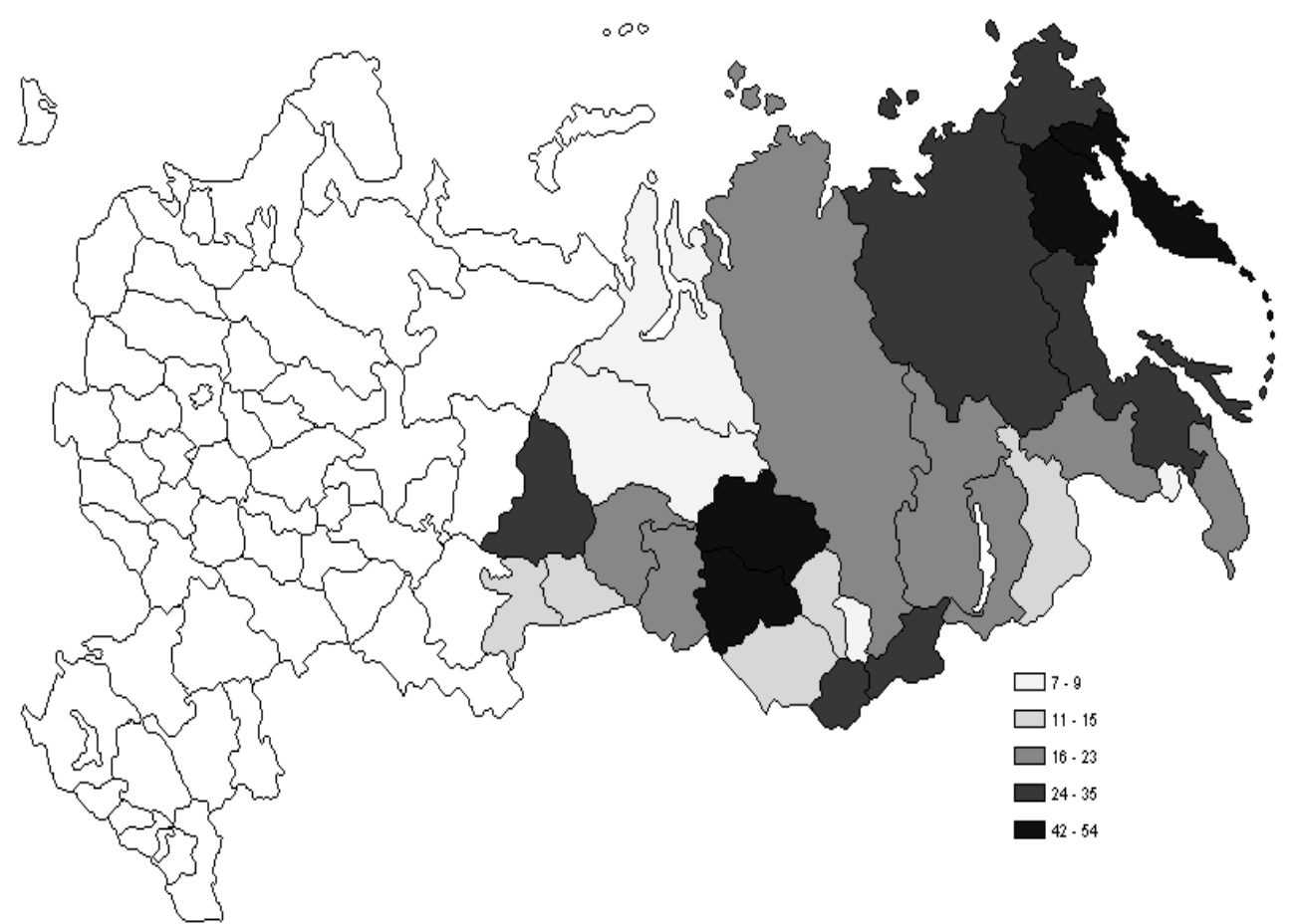

Źródło: opracowanie własne na podstawie danych na stronie www.gks.ru.

Z rysunku 6 można wyciągnąć następujące wnioski:

- zdecydowanie największa liczba organizacji badawczo-rozwojowych w przeliczeniu na 1 mln mieszkańców występowała w obwodach: swierdłowskim, nowosybirskim, magadańskim, tomskim, a także w Kraju Kamczackim, Republice Ałtaju oraz Czukockim Okręgu Autonomicznym;

- zdecydowanie najmniejsza liczba tych organizacji na $1 \mathrm{mln}$ mieszkańców była charakterystyczna dla Żydowskiego Obwodu Autonomicznego, Okręgów Autonomicznych: Jamalsko-Nienieckiego oraz Chanty-Mansyjskiego, Kraju Zabajalskiego oraz obwodów kemerowskiego i czelabińskiego. 
W tabeli 6 zestawiono grupy kwartylowe pod względem liczby organizacji o charakterze badawczo-rozwojowym w regionach części azjatyckiej FR w latach 20002012.

Tabela 6. Liczba organizacji o charakterze badawczo-rozwojowym w regionach części azjatyckiej FR w latach 2000-2012 na 1 mln mieszkańców

\begin{tabular}{|c|c|l|}
\hline $\begin{array}{c}\text { Grupa } \\
\text { kwartylowa }\end{array}$ & $\begin{array}{c}\text { Granice } \\
\text { grupy }\end{array}$ & \multicolumn{1}{c|}{ Regiony } \\
\hline 1 & $<13$ & $\begin{array}{l}\text { Żydowski Obwód Autonomiczny (7), Jamalsko-Nieniecki } \\
\text { Okręg Autonomiczny (8), Republika Chakasji (8), Chanty- } \\
\text { Mansyjski Okręg Autonomiczny (9), obwód kemerowski } \\
\text { (11), Kraj Zabajkalski (11), obwód czelabiński (13) }\end{array}$ \\
\hline 2 & $14-19$ & $\begin{array}{l}\text { Kraj Ałtajski (14), obwód kurgański (15), obwód irkucki } \\
\text { (16), Republika Buriacji (16), obwód amurski (17), obwód } \\
\text { tiumeński (17) }\end{array}$ \\
\hline 3 & $20-26$ & $\begin{array}{l}\text { Kraj Krasnojarski (20), obwód omski (21), Kraj Nadmorski } \\
\text { (23), Republika Jakucji (24), Republika Tuwy (24), obwód } \\
\text { sachaliński (25), Kraj Chabarowski (26) }\end{array}$ \\
\hline 4 & $>27$ & $\begin{array}{l}\text { Obwód swierdłowski (27), Czukocki Okręg Autonomiczny } \\
(34), \text { Republika Ałtaju (35), Kraj Kamczacki (42), obwód } \\
\text { nowosybirski (44), obwód magadański (47), obwód tomski } \\
\text { (54) }\end{array}$ \\
\hline
\end{tabular}

Źródło: opracowanie własne na podstawie danych na stronie www.gks.ru.

Rozważając dane przedstawione w tabeli 6, można zauważyć, że liczba organizacji o charakterze badawczo-rozwojowym w części azjatyckiej FR w latach 2000-2012 jest następująca:

a) najmniejsza liczba organizacji (nieprzekraczająca 13) występowała w następujących regionach: Żydowskim Obwodzie Autonomicznym (7), JamalskoNienieckim Okręgu Autonomicznym (8), Republice Chakasji (8), ChantyMansyjskim Okręgu Autonomicznym (9), obwodzie kemerowskim (11), Kraju Zabajkalskim (11), obwodzie czelabińskim (13).

$\mathrm{W}$ grupie (a) znalazły się regiony $\mathrm{z}$ dobrze rozwiniętym sektorem wydobywczym, jak w wypadku Okręgów Autonomicznych Jamalsko-Nienieckiego i Chanty-Mansyjskiego, lecz z małą liczbą mieszkańców. Z kolei w wypadku obwodu kemerowskiego występowała duża liczba mieszkańców, co zmniejsza liczbę organizacji B + R w przeliczeniu na 1 mln mieszkańców;

b) mała liczba organizacji (14-19) była charakterystyczna dla następujących regionów: Kraju Ałtajskiego (14), obwodu kurgańskiego (15), obwodu irkuckiego (16), Republiki Buriacji (16), obwodu amurskiego (17), obwodu tiumeńskiego (17);

c) duża liczbą organizacji (20-26) występowała w przedstawionych regionach: Kraju Krasnojarskim (20), obwodzie omskim (21), Kraju Nadmorskim (23), Republice Jakucji (24), Republice Tuwy (24), obwodzie sachalińskim (25), Kraju Chabarowskim (26); 
d) najwyższa liczba organizacji (od 27) charakterystyczna była dla następujących regionów: obwodu swierdłowskiego (27), Czukockiego Okręgu Autonomicznego (34), Republiki Ałtaju (35), Kraju Kamczackiego (42), obwodu nowosybirskiego (44), obwodu magadańskiego (47), obwodu tomskiego (54).

Do grupy (d) należą regiony $\mathrm{z}$ dużą liczbą organizacji $\mathrm{B}+\mathrm{R}-$ są to: obwody swierdłowski, nowosybirski, magadański oraz tomski. Specyfikę tych obwodów można wytłumaczyć ulokowaniem przemysłu na Uralu i za nim w czasach II wojny światowej przez rząd. W wypadku Czukockiego Okręgu Autonomicznego oraz Kraju Kamczackiego występowała mała liczba mieszkańców, co zwiększa liczbę organizacji $\mathrm{B}+\mathrm{R}$ w przeliczeniu na 1 mln mieszkańców.

\section{BUDOWA WSKAŹNIKA TAKSONOMICZNEGO OPARTEGO NA METRYCE EUKLIDESOWEJ}

Analizując zróżnicowanie rozwoju ekonomicznego regionów FR, należy wprowadzić pojęcia: stymulanta i destymulanta rozwoju ekonomicznego. Przez stymulantę rozwoju ekonomicznego rozumie się taką zmienną ekonomiczną, której wysoki poziom pociąga za sobą pożądany stan badanego zjawiska. Natomiast destymulanta to taka zmienna ekonomiczna, której wysoki poziom implikuje niepożądany stan badanego zjawiska ${ }^{8}$.

Statystyczna zależność między stymulantą $\left(s_{m k}^{l}\right)$ i destymulantą $\left(d_{m k}^{l}\right)$ wyraża się w następującym przekształceniu:

$$
s_{m k}^{l}=\frac{1}{d_{m k}^{l}}
$$

gdzie:

- indeksy $l, m, k$ dotyczą odpowiednio: badanego regionu, okresu, indeksu stymulanty (destymulanty).

W celu wprowadzenia taksonomicznego wskaźnika rozwoju ekonomicznego regionu opartego na odległości w metryce euklidesowej wykorzystano proces standaryzacji opisany wzorem (2). Proces standaryzacji dokonuje się w oparciu na następującym związku:

$$
\bar{s}_{m k}^{l}=\frac{s_{m k}^{l}}{\max _{l k}\left(s_{m k}^{l}\right)}
$$

gdzie:

$\bar{s}_{m k}^{l}-$ wystandaryzowana stymulanta.

Wartości $\bar{s}_{m k}^{l}$ należą do przedziału $[0,1]$, co pozwala porównać dowolne wartości różnych wystandaryzowanych stymulant.

\footnotetext{
${ }^{8}$ S. Majewski, Szeregowanie krajów przy pomocy Diagramu Czekanowskiego i Taksonomicznego Miernika Rozwoju, „Wiadomości Statatystyczne” 1999/8, s. 77.
} 
W wypadku gdy wartość symulanty równa jest 1, można to zinterpretować następująco: w l-tym regionie, w roku $k$, zmienna $m$ przyjęła maksymalną wartość w badanej grupie. Pociąga to za sobą następujący wniosek: im wyższe (niższe) wartości przyjmuje wystandaryzowana stymulanta $\left(\bar{s}_{m k}^{l}\right)$, tym odpowiednio lepszy (gorszy) jest stopień rozwoju regionu pod względem zmiennej opisywanej przez tę stymulantę.

Wśród wymienionych zmiennych przedstawione są cztery stymulanty: inwestycje per capita, PKB per capita, liczba organizacji prowadzących działalność badawczorozwojową $(\mathrm{B}+\mathrm{R})$ na $1 \mathrm{mln}$ mieszkańców i płace. Wówczas destymulantą jest stopa bezrobocia rejestrowanego. Zmienne te mogą nie odzwierciedlać precyzyjnie rozwoju $\mathrm{w}$ ujęciu regionalnym. W celu uzyskania całkowitego obrazu rozwoju regionalnego należy zastosować wskaźnik taksonomiczny oparty na metryce euklidesowej. Wskaźnik odległości euklidesowej pozwala zanalizować niezależne zmienne jako wartości bezwzględne. Takie podejście było stosowane również w analizach rozwoju powiatów w Polsce przez Tokarskiego i Jabłońskiego ${ }^{9}$ oraz Dykasa ${ }^{10}$. metryki:

Wzór (3) przedstawia odległości wystandaryzowanych stymulant od 1 dla tej

$$
W T=\sqrt{\sum_{k=1}^{T} \sum_{m=1}^{n}\left(1-\bar{s}_{m k}^{l}\right)^{2}}
$$

gdzie:

$n$ - liczba użytych stymulant,

$T$ - liczba lat w badanym okresie.

Wskaźnik taksonomiczny mierzy odległość między wzorcem teoretycznym, który przyjmuje maksymalne wartości zmiennych dla każdej stymulanty $i$-tego regionu w roku $k$. Stąd wynika, że mniejszej (większej) odległości wskaźnika towarzyszy wyższy (niższy) poziom rozwoju regionu pod względem rozważanych zmiennych. Wskaźnik WT może przyjmować wartości z przedziału $\lfloor 0, \sqrt{n T}\rfloor$, gdzie $n$ jest liczbą analizowanych stymulant.

\section{ZRÓŻNICOWANIE ROZWOJU REGIONÓW CZEŚCI AZJATYCKIEJ FEDERACJI ROSYJSKIEJ OPARTE NA WSKAŹNIKU ODLEGLOŚCI EUKLIDESOWEJ}

Analiza obejmuje 27 regionów części azjatyckiej FR w latach 2000-2012. Dane zaczerpnięto ze strony ze strony Rosyjskiego Urzędu Statystycznego (Федеральная Служба Государственной Статистки - Rosstat; www.gks.ru). Na podstawie zgromadzonych danych obliczono wartości wskaźnika dla tych regionów. Na rysunku 7 przedstawionono klasyfikację regionów części azjatyckiej FR pod względem poziomu rozwoju ekonomicznego mierzonego taksonomicznym wskaźnikiem.

\footnotetext{
${ }^{9}$ T. Tokarski, Ł. Jabłoński, Taksonomiczne wskaźniki przestrzennego zróżnicowania rozwoju powiatów, „Studia-Prawno Ekonomiczne” 2010/LXXXI.

${ }^{10} \mathrm{P}$. Dykas, Taksonomiczne wskaźniki przestrzennego zróżnicowania rozwoju powiatów województwa podkarpackiego, ,Studia-Prawno Ekonomiczne” 2010/LXXX.
} 
Z rysunku 7 wyciągnąć można następujące wnioski:

- $\quad$ zdecydowanie najlepiej rozwinięte są regiony Uralskiego Okręgu Federalnego są to na przykład Okręgi Autonomiczne: Jamało-Nieniecki, Czukocki i ChantyMansyjski oraz obwody tiumeński, sachaliński, magadański;

- do najgorzej rozwiniętych regionów w części azjatyckiej FR zaliczyć można: Kraje Ałtajski i Zabajkalski, Republiki Chakasji, Buriacji i Tuwy, Żydowski Obwód Autonomiczny oraz obwód kurgański.

Rys. 7. Klasyfikacja regionów części azjatyckiej Federacji Rosyjskiej ze względu na wartości wskaźnika taksonomicznego w latach 2000-2012

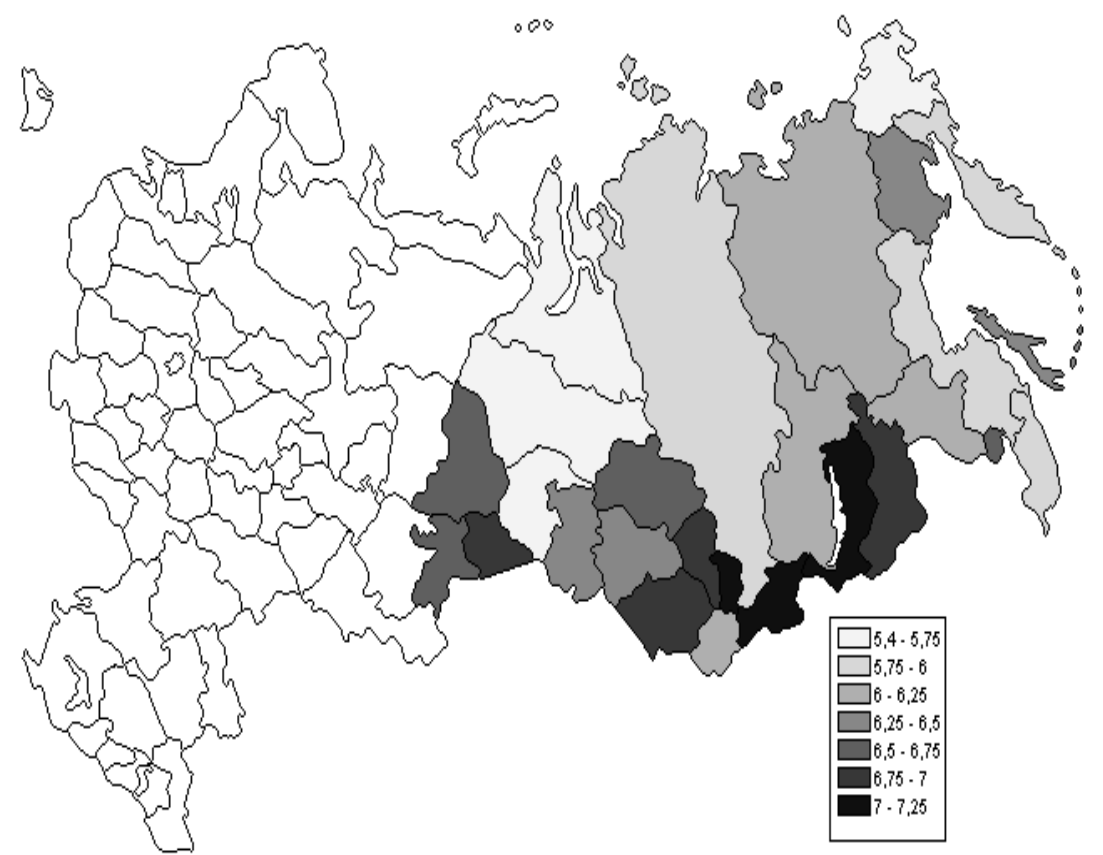

Źródło: opracowanie własne na podstawie danych na stronie www.gks.ru.

W tabeli 7 przedstawiono klasyfikację regionów części azjatyckiej FR pod względem poziomu rozwoju ekonomicznego mierzonego taksonomicznym wskaźnikiem, w podziale na grupy kwartylowe. 
Tabela 7. Klasyfikacja regionów części azjatyckiej Federacji Rosyjskiej ze względu na wartości wskaźnika taksonomicznego w latach 2000-2012

\begin{tabular}{|c|c|l|}
\hline $\begin{array}{c}\text { Grupa } \\
\text { kwartylo } \\
\text { wa }\end{array}$ & Granice grupy & \multicolumn{1}{c|}{ Regiony } \\
\hline 1 & $<6,305$ & $\begin{array}{l}\text { Jamalsko-Nieniecki Okręg Autonomiczny (5,410), } \\
\text { Czukocki Okręg Autonomiczny (5,579), obwód } \\
\text { tiumeński (5,881), Chanty-Mansyjski Okręg } \\
\text { Autonomiczny (6), obwód sachaliński (6,032), obwód } \\
\text { magadański (6,036), Kraj Kamczacki (6,278) }\end{array}$ \\
\hline 2 & $6,306-6,738$ & $\begin{array}{l}\text { Obwód tomski (6,331), Republika Jakucji (6,424), } \\
\text { obwód nowosybirski (6,533), Kraj Chabarowski } \\
\text { (6,555), obwód swierdłowski (6,615), Kraj } \\
\text { Krasnojarski (6,657), Kraj Nadmorski (6,738) }\end{array}$ \\
\hline 3 & $6,739-7,047$ & $\begin{array}{l}\text { obwód amurski (6,823), obwód czelabiński (6,840), } \\
\text { Republika Ałtaju (6,858), obwód omski (6,880), } \\
\text { obwód irkucki (6,931), obwód kemerowski (7) }\end{array}$ \\
\hline 4 & $<7,047$ & $\begin{array}{l}\text { Żydowski Obwód Autonomiczny (7,093), Republika } \\
\text { Chakasji (7,101), Republika Buriacji (7,115), Kraj } \\
\text { Ałtajski (7,129), Kraj Zabajkalski (7,131), Republika } \\
\text { Tuwy (7,142), obwód kurgański (7,152) }\end{array}$ \\
\hline
\end{tabular}

Źródło: opracowanie własne na podstawie danych na stronie www.gks.ru.

Analizując dane z tabeli 7, można zauważyć, że pod względem wartości wskaźnika taksonomicznego przestrzenne zróżnicowanie jest następujące:

a) do najbardziej rozwiniętych regionów (w których wartość wskaźnika nie przekracza 6,305) zaliczyć można: Jamalsko-Nieniecki Okręg Autonomiczny $(5,410)$, Czukocki Okręg Autonomiczny (5,579), obwód tiumeński (5,881), Chanty-Mansyjski Okręg Autonomiczny (6), obwód sachaliński (6,032), obwód magadański (6,036), Kraj Kamczacki (6,278).

Do tej grupy (a) należą regiony z najlepiej rozwiniętym przemysłem

wydobywczym lub sektorem usługowym - jak w wypadku obwodu tiumeńskiego;

b) do wysoko rozwiniętych regionów (w których wartość wskaźnika mieści się w przedziale 6,306-6,738) należą: obwód tomski (6,331), Republika Jakucji $(6,424)$, obwód nowosybirski $(6,533)$, Kraj Chabarowski $(6,555)$, obwód swierdłowski (6,615), Kraj Krasnojarski (6,657), Kraj Nadmorski (6,738);

c) do nisko rozwiniętych regionów (w których wartość wskaźnika mieści się w przedziale 6,739-7,047) zaliczyć można: obwód amurski $(6,823)$, obwód czelabiński (6,840), Republikę Ałtaju (6,858), obwód omski $(6,880)$, obwód irkucki (6,931), obwód kemerowski (7);

d) do najgorzej rozwiniętych regionów (gdzie wartość wskaźnika przekracza 7,047) należą: Żydowski Obwód Autonomiczny (7,093), Republika Chakasji $(7,101)$, 
Republika Buriacji (7,115), Kraj Ałtajski (7,129), Kraj Zabajkalski $(7,131)$, Republika Tuwy $(7,142)$, obwód kurgański $(7,152)$.

W grupie (d) znalazły się regiony ze słabo rozwiniętym przemysłem wydobywczym bądź przetwórczym. Są to w większości regiony rolnicze.

\section{WSTĘPNA ANALIZA KONWERGENCJI/DYWERGENCJI}

Niniejsza część opracowania zawiera porównanie przestrzennego zróżnicowania przedstawionych zmiennych makroekonomicznych oraz wstępną analizę procesów konwergencji/dywergencji.

Tabela 8. Wybrane wskaźniki przestrzennego zróżnicowania badanych zmiennych makroekonomicznych

\begin{tabular}{|c|r|r|r|r|r|}
\hline \multirow{2}{*}{$\begin{array}{c}\text { Wskaźnik } \\
\text { zróżnicowania }\end{array}$} & $\begin{array}{c}\text { Stopa } \\
\text { bezrobocia }\end{array}$ & $\begin{array}{c}\text { Inwestycje } \\
\text { na } \\
\text { mieszkańca }\end{array}$ & $\begin{array}{c}\text { PKB } \\
\text { per } \\
\text { capita }\end{array}$ & Płace & $\begin{array}{c}\text { Liczba } \\
\text { firm B + } \\
\text { R w } \\
\text { regionie }\end{array}$ \\
\hline Maks./min. & 4,80 & 77,35 & 13,92 & 5,35 & 11,77 \\
\hline$V_{S}$ & 0,35 & 1,50 & 0,95 & 0,52 & 0,59 \\
\hline$V_{d}$ & 0,23 & 0,94 & 0,67 & 0,40 & 0,45 \\
\hline$V_{Q}$ & 0,30 & 1,00 & 0,84 & 0,72 & 0,72 \\
\hline
\end{tabular}

$V_{S}$ - współczynnik zmienności oparty na odchyleniu standardowym; $V_{d}-$ współczynnik zmienności oparty na odchyleniu przeciętnym; $V_{Q}$ - współczynnik zmienności oparty na odchyleniu ćwiartkowym; PKB - produkt krajowy brutto; B + R - badawczo-rozwojowy Źródło: obliczenia własne na podstawie danych na stronie www.gks.ru.

W niniejszej części opracowania przeprowadzono analizę procesów konwergencji/dywergencji regionalnej. Mówiąc o konwergencji/dywergencji, należy zdefiniować owe procesy ${ }^{11}$.

Pojęcie konwergencji w świetle makroekonomii oznacza proces wyrównywania się wartości podstawowych zmiennych makroekonomicznych pomiędzy krajami czy regionami charakteryzującymi się różnymi wyjściowymi wartościami tych zmiennych. Za pomocą analizy konwergencji można odpowiedzieć na pytanie, czy regiony (kraje) różniące się istotnie wyjściowym poziomem pewnych zmiennych będą się do siebie

\footnotetext{
${ }^{11}$ Więcej informacji na ten temat por. na przykład K. Malaga, P. Kliber, Konwergencja a nierówności regionalne w Polsce w świetle neoklasycznych modeli wzrostu, Wydawnictwo Akademii Ekonomicznej w Poznaniu, Poznań 2007; P. Gajewski, T. Tokarski, Czy w Polsce wystepuje efekt konwergencji regionalnej?, „Studia Ekonomiczne” 1-2/XL-XLI (2004); T. Misiak, A. Sulima, T. Tokarski, Czy w polskich powiatach występuje efekt konwergencji realnej?, [w:] Wzrost gospodarczy i polityka makroekonomiczna, red. W. Kwiatkowska, E. Kwiatkowski, Wydawnictwo Uniwersytetu Łódzkiego, Łódź 2010, lub T. Misiak, T. Tokarski, R.W. Włodarczyk, Konwergencja czy dywergencja polskich rynków pracy, „Gospodarka Narodowa” 2011/7-8.
} 
zbliżały pod względem wielkości owych zmiennych albo czy będą się od siebie oddalały. Nadrabianie dystansu do gospodarek (regionów) najlepiej rozwiniętych oznacza proces konwergencji realnej, natomiast oddalanie się gospodarek (regionów) lepiej rozwiniętych od biedniejszej gospodarki (regionu) nazywa się procesem dywergencji.

W literaturze przedmiotu można spotkać dwie techniczne miary konwergencji są to: $\square$-konwergencja oraz $\square$-konwergencja. $\square$-konwergencja zachodzi wówczas, gdy zróżnicowanie pewnej zmiennej makroekonomicznej między regionami lub krajami zmniejsza się w czasie, natomiast $\square$-konwergencja występuje, gdy mamy do czynienia z malejącą zależnością między osiąganą stopą wzrostu gospodarczego a początkowym poziomem analizowanej zmiennej makroekonomicznej. Należy wspomnieć, że poza $\sigma$ konwergencją i $\beta$-konwergencją w literaturze przedmiotu również można również spotkać na przykład konwergencję warunkową i bezwarunkową bądź też tzw. konwergencję klubową.

Najczęściej $\sigma$-konwergencja mierzona jest przez zmiany odchylenia standardowego badanej zmiennej. Jeśli odchylenie standardowe rośnie (maleje) wraz z upływem czasu, to mówi się, że występuje proces $\sigma$-konwergencji ( $\sigma$-dywergencji).

Rys. 8. Współczynniki zmienności $\mathrm{V}_{\mathrm{S}}$ badanych zmiennych makroekonomicznych w latach 2000-2012

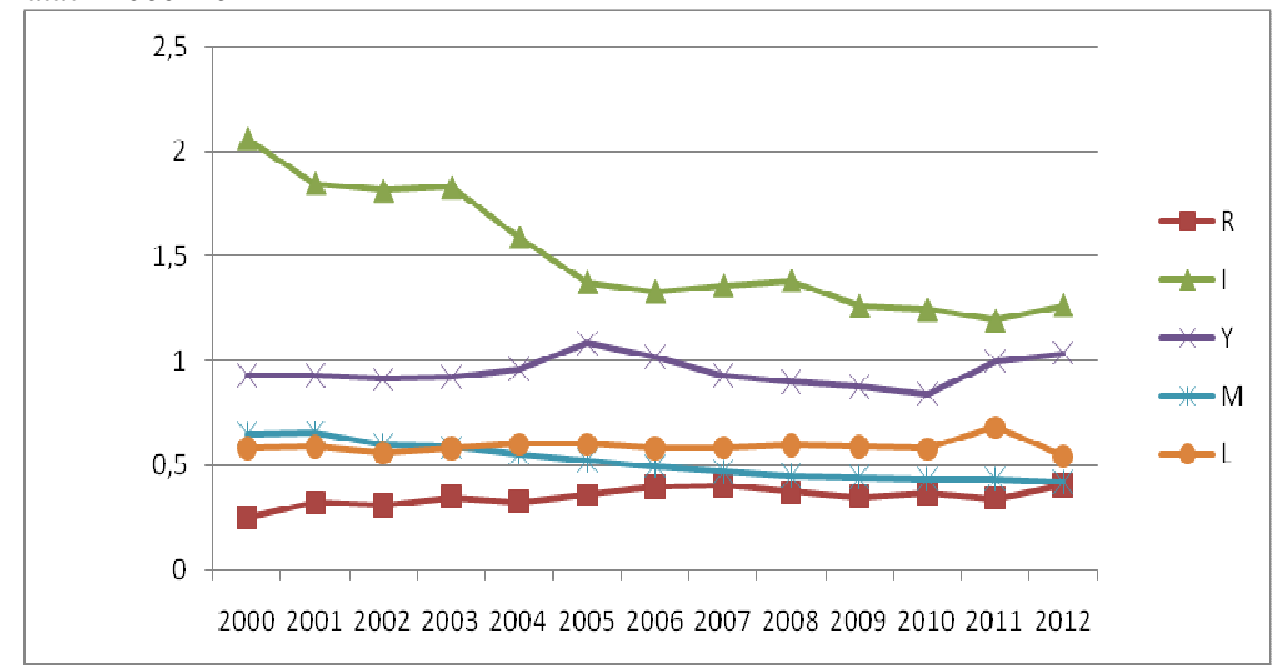

$\mathrm{R}$ - stopa bezrobocia; I - inwestycje per capita; Y - PKB per capita; M - płace; L liczba organizacji B + R

Źródło: obliczenia własne na podstawie danych na stronie www.gks.ru.

W dalszej części opracowania proces $\sigma$-konwergencji badany będzie nie za pomocą zmiany odchylenia standardowego będącego bezwzględną miarą zróżnicowania zmiennej, lecz za pomocą zmiany współczynników zmienności $V_{S}, V_{d}$ i $V_{Q}$ (które są względnymi miarami zróżnicowania). $\mathrm{Na}$ rysunkach 8-10 zilustrowano owe współczynniki zmienności. 
Rys. 9. Współczynniki zmienności $\mathrm{V}_{\mathrm{d}}$ badanych zmiennych makroekonomicznych w latach 2000-2012

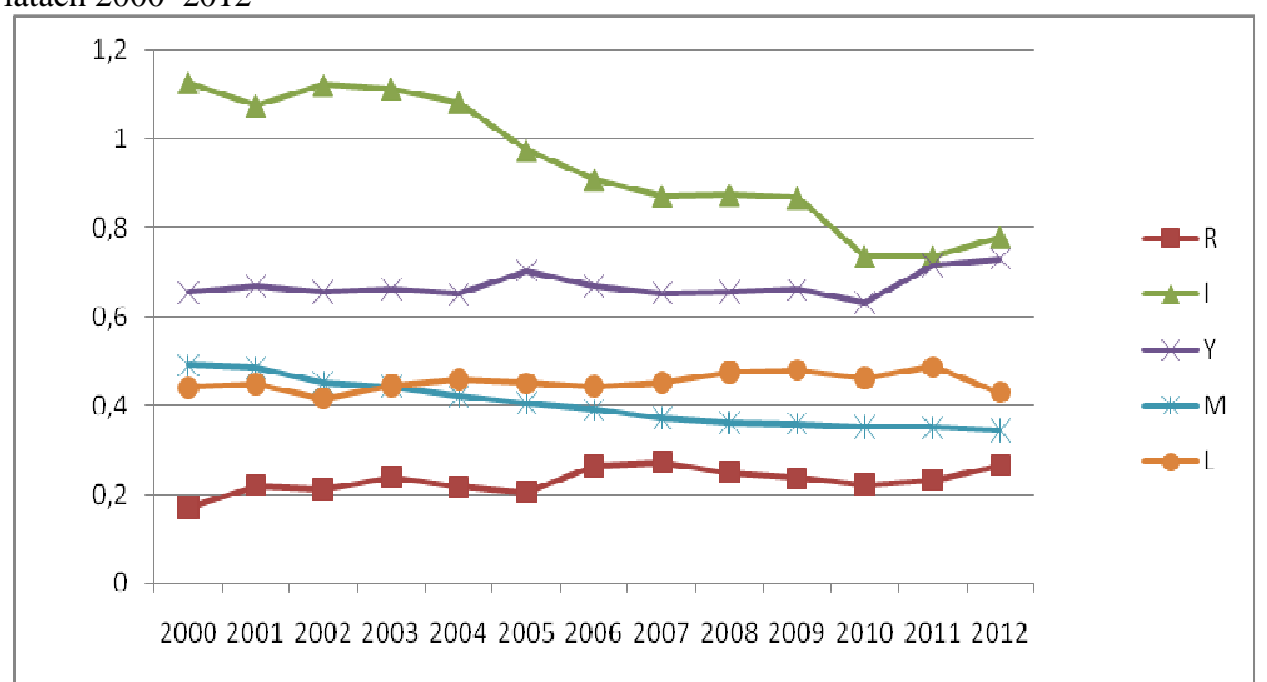

$\mathrm{R}$ - stopa bezrobocia; I - inwestycje per capita; Y - PKB per capita; M - płace; L liczba organizacji $\mathrm{B}+\mathrm{R}$

Źródło: obliczenia własne na podstawie danych na stronie www.gks.ru.

Rys. 10. Współczynniki zmienności $\mathrm{V}_{\mathrm{Q}}$ badanych zmiennych makroekonomicznych w latach 2000-2012

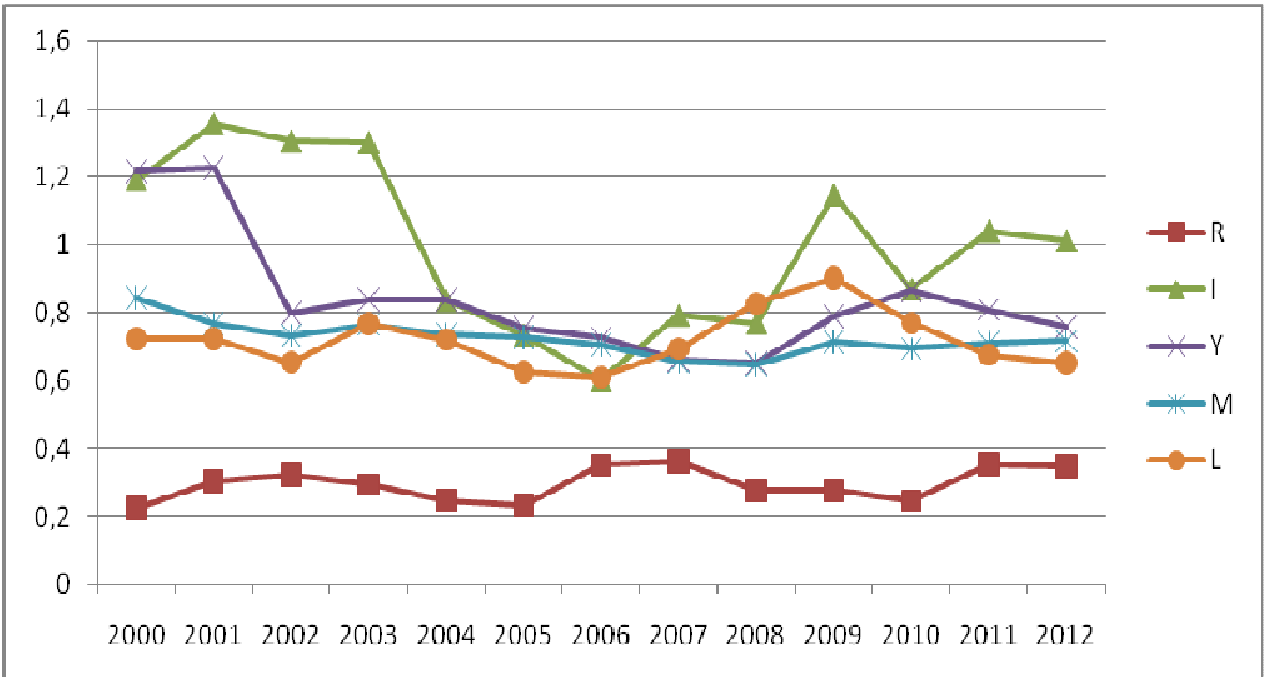

$\mathrm{R}$ - stopa bezrobocia; I - inwestycje per capita; Y - PKB per capita; M - płace; L liczba organizacji B + R

Źródło: obliczenia własne na podstawie danych na stronie www.gks.ru. 
Z przedstawionych rysunków 8-10 można można zaobserwować, że proces przestrzennej $\sigma$-konwergencji w regionach części azjatyckiej FR dotyczył następujących wskaźników makroekonomicznych:

- $\quad$ inwestycje na mieszkańca - współczynnik zmienności $V_{S}$ spadł z poziomu okołó 2,06 w roku 2000 do 1,27 w 2012 r., $V_{d}$ z 1,13 do 0,78, $V_{Q}$ zaś z 1,19 do 1,01;

- $\quad$ płace - współczynnik zmienności $V_{S}$ spadł z poziomu około 0,64 w roku 2000 do 0,42 w 2012 r., $V_{d}$ z 0,49 do $0,35, V_{Q}$ zaś z 0,84 do 0,72 ;

- $\quad$ liczba organizacji B + R w przeliczeniu na 1 mln mieszkańców - współczynnik zmienności $V_{S}$ spadł z poziomu około $0,58 \mathrm{w}$ roku 2000 do $0,54 \mathrm{w} 2012$ r., $V_{d}$ z 0,44 do $0,43, V_{Q}$ zaś z 0,72 do 0,65 .

Proces konwergencji nie dotyczył przestrzennego zróżnicowania PKB per capita, ponieważ analizowane współczynniki zmienności w niektórych latach rosły, a w niektórych malały. O procesie $\sigma$-dywergencji można zaś mówić w wypadku rejestrowanej stopy bezrobocia. Współczynniki zmienności zmieniały się w wypadku tej zmiennej makroekonomicznej od $0,25 \mathrm{w}$ roku 2000 do $0,41 \mathrm{w} 2012$ roku $\left(V_{S}\right)$, od 0,17 do $0,27\left(V_{d}\right)$ oraz od 0,23 do $0,35\left(V_{Q}\right)$.

\section{PODSUMOWANIE}

$\mathrm{W}$ artykule zaprezentowano analizę $\sigma$-konwergencji/dywergencji oraz statystyczną analizę poziomu rozwoju regionów części azjatyckiej FR w latach 2000-2012. Regiony porównano pod względem: stóp bezrobocia rejestrowanego, płac, inwestycji per capita, liczby organizacji o charakterze $\mathrm{B}+\mathrm{R}$ na 1 mln mieszkańców oraz PKB per capita. Poziom rozwoju gospodarczego owych regionów można powiązać ze strukturą gospodarki regionu. Przemysł wydobywczy, przetwórstwo ropy naftowej i gazu ziemnego oraz prace badawczo-rozwojowe sprzyjają wzrostowi inwestycji, z kolei dobrze rozwinięty sektor usługowy wspiera wzrost płac i zatrudnienia. Dodatkowo poziom rozwoju został także ujęty za pomocą wskaźnika taksonomicznego. Z opracowania płyną następujące wnioski: do najbardziej rozwiniętych regionów części azjatyckiej FR można zaliczyć następujące Okręgi Autonomiczne: Jamalsko-Nieniecki, Chanty-Mansyjski oraz Czukocki, a także Kraj Kamczacki, obwody: tiumeński, magadański oraz sachaliński.

W wypadku Okręgów Autonomicznych Chanty-Mansyjskiego, JamalskoNienieckiego występują dobrze rozwinięty przemysł wydobycia ropy i gazu ziemnego, elektroenergetyczny, przetwórstwo ropy naftowej i gazu ziemnego, przemysł spożywczy, prace badawczo-rozwojowe oraz przemysł farmaceutyczny. Warto podkreślić, że ChantyMansyjski Okręg Autonomiczny charakteryzuje się największym udziałem w wydobyciu ropy i gazu ziemnego w FR.

W obwodzie sachalińckim występują dobrze rozwinięty przemysł wydobywczy, zwłaszcza wydobycie węgla kamiennego oraz brunatnego, ropy naftowej i gazu ziemnego. Ponadto obwód sachaliński według Ministerstwa Rozwoju Regionalnego FR (Министерство Регионального Развития) zajmuje pierwsze miejsce pod względem rozwoju realnej gospodarki regionu za 2012 r., co sprawia, że dany region jest jednym z najbardziej atrakcyjnych regionów FR dla inwestorów. Z kolei obwód magadański charakteryzuje się dużymi złożami metalów szlachetnych oraz małą liczbą mieszkańców. W obwodach swierdłowskim, omskim, tiumeńskim występują: pracą $\mathrm{B}+\mathrm{R}$, dobrze rozwinięty przemysł przetwórstwa ropy naftowej i gazu ziemnego, spożywczy oraz 
elektroenergetyczny. Wymieniona specyfika przemysłu w obwodach bierze początek z lat czterdziestych XX wieku, kiedy podczas II wojny światowej rząd Związku Radzieckiego przeniósł ciężki przemysł na Ural i Syberię. Duży wpływ na pozycję regionu mają inwestycje związane $\mathrm{z}$ nakładami na prace $\mathrm{B}+\mathrm{R}$. Inwestycje wiążą się ze wzrostem zatrudnienia, płac oraz liczby organizacji badawczo-rozwojowych.

Do najgorzej rozwiniętych regionów można zaliczyć następujące regiony: Żydowski Obwód Autonomiczny, Republikę Chakasji, Republikę Buriacji, Kraj Ałtajski, Kraj Zabajkalski, Republika Tuwy oraz obwód kurgański. Są to w większości regiony rolnicze ze słabo rozwiniętym sektorem usługowym. Z kolei Żydowski Obwód Autonomiczny charakteryzuje się brakiem sektora przemysłowego oraz małą liczbą mieszkańców.

\section{LITERATURA}

[1] Adamczyk A., Tokarski T., Włodarczyk R.W., Przestrzenne zróżnicowanie płac w Polsce, „Gospodarka Narodowa” 2009/9.

[2] Dykas P., Taksonomiczne wskaźniki przestrzennego zróżnicowania rozwoju powiatów województwa podkarpackiego, „Studia-Prawno Ekonomiczne” 2010/LXXX.

[3] Gajewski P., Konwergencja regionalna w Polsce, praca doktorska napisana w Katedrze Makroekonomii Uniwersytetu Łódzkiego pod kierunkiem T. Tokarskiego, Łódź.

[4] Gajewski P., Tokarski T., Czy w Polsce występuje efekt konwergencji regionalnej?, „Studia Ekonomiczne” 1-2/XL-XLI (2004).

[5] Kornowski A., Zróżnicowanie rozwoju ekonomicznego regionów Federacji Rosyjskiej, ,Studia-Prawno Ekonomiczne” 2013/ LXXXVII.

[6] Majewski S., Szeregowanie krajów przy pomocy Diagramu Czekanowskiego i Taksonomicznego Miernika Rozwoju, „Wiadomości Statatystyczne” 1999/8.

[7] Malaga K., Kliber P., Konwergencja a nierówności regionalne $w$ Polsce $w$ świetle neoklasycznych modeli wzrostu, Wydawnictwo Akademii Ekonomicznej w Poznaniu, Poznań 2007.

[8] Misiak T., Sulima A., Tokarski T., Czy w polskich powiatach występuje efekt konwergencji realnej?, [w:] Wzrost gospodarczy i polityka makroekonomiczna, red. W. Kwiatkowska, E. Kwiatkowski, Wydawnictwo Uniwersytetu Łódzkiego, Łódź 2010.

[9] Misiak T., Tokarski T., Włodarczyk R.W., Konwergencja czy dywergencja polskich rynków pracy, ,Gospodarka Narodowa” 2011/7-8.

[10] Przeobrażenia gospodarki polskiej w przededniu integracji z Uniq Europejska, red. K.B. Matusiak, Wyższa Szkoła Ekonomiczno-Społeczna w Ostrołęce, Ostrołęka 2004.

[11]Tokarski T., Jabłoński Ł., Taksonomiczne wskaźniki przestrzennego zróżnicowania rozwoju powiatów, „Studia-Prawno Ekonomiczne” 2010/LXXXI.

[12] Instytut Gospodarki Przestrzennej (Институт территориального планирования), www.urbanica.spb.ru.

[13] Rosyjski Urząd Statystyczny (Федеральная служба государственной статистики. Росстат), www.gks.ru.

[14] Ministerstwo Rozwoju Regionalnego (Министерство Регионального Развития), www.minregion.ru. 


\section{DIFFERENTIATION OF MACROECONOMIC VARIABLES AND ECONOMIC DEVELOPMENT FOR THE ASIAN REGIONS OF THE RUSSIAN FEDERATION}

The main aim of this article is an analysis of the spatial differentiation of macroeconomic variables and economic development for the Asian regions of the Russian Federation with five basic macroeconomic variables, namely: unemployment rates registered, investment per capita, GDP per capita, wages, number of research and development organizations per million people in the years 2000-2012. The work reflects on 27 Asian regions of the Russian Federation, and the data used for the analysis comes from the Russian Statistical Office (Федеральная служба государственной статистики. Росстат; www.gks.ru). The basic methods of the analysis are based on the taxonomic index Euclidean and analysis of the of the convergence/divergence.

The differentiation of development shows the specificity of the Asian regions of Russian Federation. The analysis leads to the conclusion that the most developed in terms of the variables analyzed regions are industrial and oil production. The least developed regions are agricultural.

In the second section there will be discussed the spatial differentiation of macroeconomic variables in Russian Federation regions, namely: unemployment rates registered, investment per capita, GDP per capita, wages, number of research and development organizations per million people in the years 2000-2012; section 3 presents the construction of taxonomic index based on the Euclidean metric; section 4 presents an analysis of the diversity of regional development based on the taxonomic indicators; in section 5 the analysis of convergence / divergence is shown, while section 6 contains a summary and important conclusions.

Keywords: Russian Federation, Asian regions of Russian Federation, economic development, differentiation of macroeconomic variables.

DOI:10.7862/rz.2015.hss.5

Przesłano do redakcji: wrzesień 2014

Przyjęto do druku: czerwiec 2015 